\title{
Sistem Pendukung Keputusan Pemilihan Tenaga Kerja Indonesia (TKI) Berdasarkan Kualitas Untuk Menentukan Tempat Kerja Menggunakan Metode Profile Matching (Studi Kasus: PT Adila Prezkifarindo Duta)
}

\author{
Dasarius Gulo \\ Program Studi Teknik Informatika, STMIK Budi Darma, Medan, Indonesia \\ Email: dasariusgulo@gmail.com
}

\begin{abstract}
Abstrak-Dalam proses pemilihan Tenaga Kerja Indonesia (TKI) berdasarkan kualitas pada PT. Adila Prezkifarindo Duta tergolong masih manual, dimana belum ada sebuah sistem untuk pemilihan TKI yang berkualitas sehingga memerlukan waktu yang lama untuk penilaiannya serta proses pemilihan yang dilakukan kurang efektif. Untuk mendukung pengambilan keputusan dalam pemilihan Tenaga Kerja Indonesia (TKI) yang berkualitas agar lebih mudah yaitu dengan menggunakan sistem pendukung keputusan. Salah satu metode yang digunakan dalam pemilihan Tenaga Kerja Indonesia yang berkualitas adalah metode Profile Matching. Metode profile matching adalah sebuah mekanisme pengambilan keputusan dengan mengansumsikan bahwa terdapat tingkat variabel prediktor yang ideal yang harus dipenuhi oleh pelamar, bukannya tingkat minimal yang harus dipenuhi atau dilewati. Dalam proses profile matching akan dilakukan proses membandingkan antara kompetensi individu ke dalam kompetensi standar sehingga dapat diketahui perbedaan kompetensinya (disebut juga Gap). Semakin kecil Gap yang dihasilkan maka bobot nilainya semakin besar. Dalam pencocokan profil ini, calon TKI yang dipilih adalah Tenaga Kerja Indonesia yang paling mendekati profil ideal seorang TKI yang berkualitas.
\end{abstract}

Kata Kunci: Sistem Pendukung Keputusan, Pemilihan TKI Berdasarkan Kualitas, Profile Matching

Abstract-In the process of selecting Indonesian Workers (TKI) based on quality at PT. Adila Prezkifarindo Duta is classified as still manual, where there is not yet a system for selecting quality migrant workers so it requires a long time for its assessment and the selection process is less effective. To support decision making in the selection of qualified Indonesian Workers (TKI) to make it easier by using a decision support system. One method used in the selection of qualified Indonesian Workers is the Profile Matching method. The profile matching method is a decision-making mechanism by assuming that there is an ideal level of predictor variables that must be met by applicants, rather than the minimum level that must be met or passed. In the profile matching process a process will be compared between individual competencies into standard competencies so that different competencies can be identified (also called Gap). The smaller the gap produced, the greater the weight value. In matching this profile, the selected TKI candidates are Indonesian Workers who are closest to the ideal profile of a qualified TKI.

Keywords: Decision Support System, Selection of TKI Based on Quality, Profile Matching

\section{PENDAHULUAN}

Indonesia merupakan negara yang padat penduduk, namun belum memiliki lapangan pekerjaan yang cukup untuk peningkatan taraf hidup penduduk. Terbatasnya lapangan kerja di dalam Negeri dan tingkat pendapatan ekonomi keluarga yang rendah mendorong banyak penduduk menjadi Tenaga Kerja Indonesia (TKI) untuk mengadu nasib ke Luar Negeri dan banyaknya minat masyarakat untuk bekerja di Luar Negeri.

Tenaga Kerja Indonesia (TKI) merupakan program pemerintah yang mengkoordinasikan, melaksanakan pendaftaran dan pemilihan calon TKI yang berkualitas dan bertujuan untuk meningkatkan kualitas sumber daya manusia melalui pelatihan demi peningkatan kesejahteraan TKI dan keluarganya dengan memanfaatkan kesempatan kerja internasional yang tersedia.

PT. Adila Prezkifarindo Duta adalah sebuah perusahaan yang bergerak di bidang jasa penempatan Tenaga Kerja Indonesia swasta ke Luar Negeri dengan tujuan penempatan yaitu ke Malaysia. Pemilihan Tenaga Kerja Indonesia (TKI) merupakan kegiatan yang dilakukan oleh PT. Adila Prezkifarindo Duta untuk memilih calon Tenaga Kerja Indonesia yang berkualitas dan layak untuk mendapatkan tempat kerja ke Luar Negeri.

Dalam proses pemilihan Tenaga Kerja Indonesia berdasarkan kualitas tergolong masih manual, dimana belum ada sebuah sistem untuk pemilihan TKI yang berkualitas sehingga memerlukan waktu yang lama untuk penilaiannya serta proses pemilihan yang dilakukan kurang efektif. Untuk mendukung pengambilan keputusan dalam pemilihan Tenaga Kerja Indonesia (TKI) yang berkualitas agar lebih mudah yaitu dengan menggunakan sistem pendukung keputusan. Salah satu metode yang digunakan dalam pemilihan Tenaga Kerja Indonesia yang berkualitas adalah metode Profile Matching.

Profile Matching adalah sebuah mekanisme pengambilan keputusan dengan mengasumsikan bahwa terdapat tingkat variabel prediktor yang ideal yang harus dipenuhi oleh pelamar, bukannya tingkat minimal yang harus dipenuhi atau dilewati[1]. Dalam proses profile matching akan dilakukan proses membandingkan antara kompetensi individu ke dalam kompetensi standar, sehingga dapat diketahui perbedaan kompetensinya (disebut juga Gap). Semakin kecil Gap yang dihasilkan maka bobot nilainya semakin besar.

Pada penelitian sebelumnya menggunakan metode Profile Matching pernah diteliti oleh Heru Purwanto dengan judul penerapan metode profile matching dalam sistem pendukung keputusan penilaian kinerja karyawan 
pada PT. Hyundal Mobil Indonesia Cabang Kalimalang[2], dan juga pernah diteliti oleh Andri Anto Tri Susilo dengan judul penerapan metode profile matching pada sistem pendukung keputusan pemilihan ketua program studi (Studi Kasus: Program Studi Teknik Informatika STMIK Musi Rawas)[3], menjelaskan bahwa metode Profile Matching dapat direkomendasikan sebagai salah satu alternatif yang dapat membantu dalam pengambilan keputusan terutama dalam kegiatan organisasi dan manajemen sumber daya manusia yang baik dan akan berdampak positif untuk perkembangan dan kemajuan organisasi atau perusahaan..

\section{METODE PENELITIAN}

\subsection{Sistem Pendukung Keputusan}

Sistem pendukung keputusan (Decision Support System) merupakan suatu sistem informasi interaktif yang menyediakan informasi, pemodelan dan pemanipulasian data. Sistem ini digunakan untuk membantu pengambilan keputusan dalam situasi yang semiterstruktur dan situasi yang tidak terstruktur[1].

\subsection{Prifile Matching}

Profile Matching atau pencocokan profil adalah sebuah mekanisme pengambilan keputusan dengan mengasumsikan bahwa terdapat tingkat variabel prediktor yang ideal yang harus dimiliki oleh pelamar, bukannya tingkat minimal yang harus dipenuhi atau dilewati.

Dalam proses profile matching secara garis besar merupakan proses membandingkan antara kompetensi individu ke dalam kompetensi standar sehingga dapat diketahui perbedaan kompetensinya (disebut juga Gap). semakin kecil gap yang dihasilkan maka bobot nilainya semakin besar, berarti memiliki peluang lebih besar bagi seorang calon Tenaga Kerja Indonesia untuk bisa diterima. Dalam hal ini metode profile matching akan membantu pengguna dalam membuat sebuah pengambilan keputusan untuk membuat hasil yang tepat sesuai kriteria yang digunakan.

\section{HASIL DAN PEMBAHASAN}

Masalah pemilihan Tenaga Kerja Indonesia (TKI) berdasarkan kualitas yang sedang berjalan selama ini pada PT. Adila Prezkifarindo Duta masih tergolong manual, dimana belum ada sistem yang membantu dalam pemilihan TKI yang berkualitas sehingga memerlukan waktu yang lama untuk penilaiannya serta proses pemilihan yang dilakukan kurang efektif. Oleh karena itu diperlukan metode-metode untuk mendapatkan hasil penilaian yang lebih baik lagi.

Berdasarkan masalah tersebut, maka perlu dirancang suatu aplikasi sistem pendukung keputusan dalam pemilihan Tenaga Kerja Indonesia yang berkualitas pada PT. Adila Prezkifarindo Duta dengan menerapkan metode Profile Matching yang dapat membantu dalam melakukan penilaian dan pengambilan keputusan memilih TKI yang berkualitas dengan lebih akurat.

Masalah pemilihan Tenaga Kerja Indonesia (TKI) berdasarkan kualitas yang sedang berjalan selama ini pada PT. Adila Prezkifarindo Duta masih tergolong manual, dimana belum ada sistem yang membantu dalam pemilihan TKI yang berkualitas sehingga memerlukan waktu yang lama untuk penilaiannya serta proses pemilihan yang dilakukan kurang efektif. Oleh karena itu diperlukan metode-metode untuk mendapatkan hasil penilaian yang lebih baik lagi.

Berdasarkan masalah tersebut, maka perlu dirancang suatu aplikasi sistem pendukung keputusan dalam pemilihan Tenaga Kerja Indonesia yang berkualitas pada PT. Adila Prezkifarindo Duta dengan menerapkan metode Profile Matching yang dapat membantu dalam melakukan penilaian dan pengambilan keputusan memilih TKI yang berkualitas dengan lebih akurat.

Data Alternatif berperan penting dalam proses pemilihan Tenaga Kerja Indonesia berdasarkan kualitas. Alternatif yang dimaksud merupakan nama-nama calon TKI yang sudah lewat seleksi berkas dokumen. Beberapa alternaif-alternatif dapat dilihat pada tabel 1 . berikut.

Tabel 1. Data Alternatif

\begin{tabular}{ll}
\hline No & Nama Calon TKI \\
\hline 1 & Indah Pratiwi \\
2 & Utami Sari \\
3 & Reni Ramadhani \\
4 & Shinta Maulida \\
5 & Renata Ulina Ginting \\
\hline
\end{tabular}

Dalam pemilihan Tenaga Kerja Indonesia berdasarkan kualitas, terdapat beberapa kriteria yang bisa menjadi acuan sebagai bahan pertimbangan. Adapun kriteria-kriteria yang akan menjadi bahan pertimbangan dapat dilihat pada tabel 2: 
Tabel 2. Keterangan Aspek Kriteria

\begin{tabular}{|c|c|}
\hline Kriteria & Keterangan Sub Kriteria \\
\hline \multirow[t]{5}{*}{ Pendidikan Terakhir } & SMA : Sekolah Menengah Atas \\
\hline & D1 : Diploma 1 \\
\hline & D3 : Diploma 3 \\
\hline & D4 : Diploma 4 \\
\hline & S1 : Strata 1 \\
\hline \multirow[t]{6}{*}{ Kapasitas Intelektual } & PN : Pengetahuan (Knowledge) \\
\hline & KE : Keahlian (Skill) \\
\hline & KA : Kemampuan Analisis \\
\hline & KR : Kreativitas \\
\hline & PR : Prestasi Kerja \\
\hline & IQ : Potensi Kecerdasan \\
\hline \multirow[t]{6}{*}{ Sikap Kerja } & LY : Loyalitas \\
\hline & KS : Kerjasama \\
\hline & TJ : Tanggung Jawab \\
\hline & $\mathrm{KC}:$ Kecakapan \\
\hline & KJ : Kejujuran \\
\hline & KD: Kedisiplinan \\
\hline \multirow[t]{5}{*}{ Pengalaman Kerja } & PK1 : 0 Tahun \\
\hline & PK2 $:<1$ Tahun \\
\hline & PK3 : $2-3$ Tahun \\
\hline & PK4 : $4-5$ Tahun \\
\hline & PK5 : > 5 Tahun \\
\hline
\end{tabular}

Dari masing-masing kriteria tersebut akan ditentukan bobot-bobotnya. Pada bobot terdiri dari 5 bilangan fuzzy yaitu Sangat Buruk (SBR), Buruk (BR), Cukup (C), Baik (B), Sangat Baik (SB). Penulis membuat kemudahan dengan menyetarakan kedalam bilangan bulat yang terdapat pada tabel di bawah ini :

Tabel 3. Nilai Bobot Kriteria Sesuai Bilangan Fuzzy

\begin{tabular}{lll}
\hline \multicolumn{1}{c}{ Bilangan Fuzzy } & Nilai \\
Sangat Buruk & 1 & \\
Buruk & 2 & \\
Cukup & 3 & \\
Baik & 4 & \\
Sangat Baik & 5 & \\
\hline
\end{tabular}

Berdasarkan kriteria dan rating kecocokan setiap alternatif pada setiap kriteria yang telah ditentukan, selanjutnya penjabaran bobot dari setiap kriteria yang telah dikonversikan dengan bilangan fuzzy. Berikut penjabaran bobot dari setiap kriteria:

1. Kriteria Pendidikan Terakhir

Kriteria pendidikan terakhir memiliki tingkat kepentingan dalam pemilihan Tenaga Kerja Indonesia yang berkualitas. Adapaun nilai bobot pada kriteria pendidikan terakhir dapat dilihat pada tabel 4 . berikut ini.

Tabel 4. Bobot Kriteria Pendidikan Terakhir

\begin{tabular}{lll}
\hline Pendidikan Terakhir (C1) & Bilangan Fuzzy & Bobot \\
\hline SMA & Sangat Buruk & 1 \\
D1 & Buruk & 2 \\
D3 & Cukup & 3 \\
D4 & Baik & 4 \\
S1 & Sangat Baik & 5 \\
\hline
\end{tabular}

2. Kriteria Kapasitas Intelektual

Kriteria kapasitas intelektual merupakan salah satu faktor utama dalam penilaian pemilihan TKI yang berkualitas, yang terdiri pengetahuan, keahlian, kemampuan, ketelitian, penalaran dan logis, kreativitas, pertasi kerja dan potensi kecerdasan. Adapun nilai bobot pada kriteria pendidikan terakhir dapat dilihat pada tabel 5. berikut ini.

Tabel 5. Bobot Kriteria Kapasitas Intelektual

\begin{tabular}{lll}
\hline Kapasitas Intelektual (C2) & Bilangan Fuzzy & Bobot \\
\hline PN: Pengetahuan & Sangat Baik & 5 \\
KE: Keahlian & Baik & 4 \\
\hline
\end{tabular}




\begin{tabular}{lll}
\hline KA: Kemampuan Analisis & Baik & 4 \\
KR: Kreativitas & Buruk & 2 \\
PR : Prestasi Kerja & Cukup & 3 \\
IQ : Potensi Kecerdasan & Baik & 4 \\
\hline
\end{tabular}

3. Kriteria Sikap Kerja

Adapaun nilai bobot pada kriteria Sikap Kerja dapat dilihat pada tabel 6. berikut ini.

Tabel 6. Bobot Kriteria Sikap Kerja

\begin{tabular}{lll}
\hline Sikap Kerja (C3) & Bilangan Fuzzy & Bobot \\
\hline KY: Loyalitas & Sangat Baik & 5 \\
KS : Kerja Sama & Baik & 4 \\
TJ : Tanggung Jawab & Baik & 4 \\
KC : Kecakapan & Cukup & 3 \\
KJ : Kejujuran & Cukup & 3 \\
KD: Kedisiplinan & Buruk & 2 \\
\hline
\end{tabular}

4. Kriteria Pengalaman Kerja

Adapaun nilai bobot pada kriteria pengalaman kerja dapat dilihat pada tabel 7. berikut ini.

Tabel 7. Bobot Kriteria Pengalaman Kerja

\begin{tabular}{lll}
\hline Pengalaman Kerja (C4) & Bilangan Fuzzy & Bobot \\
\hline 0 Tahun & Sangat Buruk & 1 \\
< 1 Tahun & Buruk & 2 \\
2 - 3 Tahun & Cukup & 3 \\
4 - 5 Tahun & Baik & 4 \\
> 5 Tahun & Sangat Baik & 5 \\
\hline
\end{tabular}

\subsection{Penerapan Metode Profile Matching}

Adapun langkah-langkah yang dilakukan dalam pemilihan Tenaga Kerja Indonesia berdasarkan kualitas menggunakan metode Profile Matching adalah sebagai berikut:

1. Perhitungan Pemetaan GAP Kompetensi Berdasarkan Kriteria

Dalam proses pemilihan calon Tenaga Kerja Indonesia (TKI) yang berkualitas penulis menggunakan perhitungan pemetaan gap kompetensi dimana yang dimaksud dengan gap disini adalah beda antara profil jabatan dengan profil individu/peserta calon Tenaga Kerja Indonesia atau dapat ditunjukkan pada rumus di bawah ini:

\section{GAP = Profil Individu - Profil Jabatan}

Keterangan :

Gap : Selisih/jarak nilai profil

Profil Individu : Nilai profil setiap individu

Profil standar : Nilai profil jabatan

Untuk lebih jelasnya perhitungan pemetaan gap kompetensi akan dipaparkan untuk tiap aspek kriterianya, meliputi:

a. Pendidikan Terakhir

Pada aspek ini, setelah dilakukan proses perhitungan gap antara profil individu dengan profil jabatan untuk masing-masing aspeknya dimana dalam aspek pendidikan terakhir ini berjumlah 5 sub aspek. Perhitungannya bisa dilihat pada tabel 8 . berikut:

Tabel 8. Pendidikan Terakhir untuk Pengelompokan Gap

\begin{tabular}{lllllll}
\hline \multirow{2}{*}{ No } & Nama & SMA & D1 & D3 & D4 & S1 \\
\cline { 2 - 6 } & Faktor Kriteria & SF & SF & CF & CF & CF \\
\hline 1 & Indah Pratiwi & 2 & 1 & $\mathbf{3}$ & 1 & 1 \\
2 & Utami Sari & $\mathbf{1}$ & 1 & 1 & 1 & 1 \\
3 & Reni Ramadhani & 3 & 1 & 1 & 1 & $\mathbf{5}$ \\
4 & Shinta Maulida & 2 & $\mathbf{2}$ & 1 & 1 & 1 \\
5 & Deni Ananda & 2 & 1 & 1 & $\mathbf{4}$ & 1 \\
Profile & Indah Pratiwi & -1 & -2 & -1 & -1 & -3 \\
1 & Utami Sari & -2 & -2 & -3 & -1 & -3 \\
2 & Reni Ramadhani & 0 & -2 & -3 & -1 & 1 \\
3 & Shinta Maulida & -1 & -1 & -3 & -1 & -3 \\
5 & Deni Ananda & -1 & -2 & -3 & 2 & -3 \\
\hline
\end{tabular}


2. Penentuan Bobot Gap

Setelah didapatkan tiap gap masing-masing calon TKI maka tiap profil TKI diberi bobot nilai gap seperti yang dapat dilihat pada tabel 9.:

Tabel 9. Keterangan Bobot Nilai Gap

\begin{tabular}{llll}
\hline No & Selisih Gap & Bobot Nilai & Keterangan \\
\hline 1 & 0 & 5 & Tidak ada selisih (Kompentensi sesuai dengan yang dibutuhkan) \\
2 & 1 & 4,5 & Kompetensi individu kelebihan 1 tingkat/level \\
3 & -1 & 4 & Kompetensi individu kurang 1 tingkat/level \\
4 & 2 & 3,5 & Kompetensi individu kelebihan 2 tingkat/level \\
5 & -2 & 3 & Kompetensi individu kurang 2 tingkat/level \\
6 & 3 & 2,5 & Kompetensi individu kelebihan 3 tingkat/level \\
7 & -3 & 2 & Kompetensi individu kurang 3 tingkat/level \\
8 & 4 & 1,5 & Kompetensi individu kelebihan 4 tingkat/level \\
9 & -4 & 1 & Kompetensi individu kurang 4 tingkat/level \\
\hline
\end{tabular}

Tiap calon TKI akan memiliki tabel bobot nilai seperti yang ada pada tabel di bawah ini :

Tabel 10. Hasil Bobot Nilai Gap Pendidikan Terakhir

\begin{tabular}{lllllll}
\hline No & Nama & SMA & D1 & D3 & D4 & S1 \\
\hline 1 & Indah Pratiwi & -1 & -2 & -1 & -1 & -3 \\
2 & Utami Sari & -2 & -2 & -3 & -1 & -3 \\
3 & Reni Ramadhani & 0 & -2 & -3 & -1 & 1 \\
4 & Shinta Maulida & -1 & -1 & -3 & -1 & -3 \\
5 & Deni Ananda & -1 & -2 & -3 & 2 & -3 \\
Keterangan bobot nilai gap & & & & & \\
1 & Indah Pratiwi & 4 & 3 & 4 & 4 & 2 \\
2 & Utami Sari & 3 & 3 & 2 & 4 & 2 \\
3 & Reni Ramadhani & 5 & 4 & 2 & 4 & 4,5 \\
4 & Shinta Maulida & 4 & 4 & 2 & 4 & 2 \\
5 & Deni Ananda & 4 & 3 & 2 & 3,5 & 2 \\
\hline
\end{tabular}

3. Perhitungan dan Pengelompokan Core Factor dan Scondary Factor

Untuk perhitungan core factor dan scondary factor dapat ditunjukkan pada rumus di bawah ini :

$\mathrm{NCF}=\frac{\sum \mathrm{NC}}{\sum \mathrm{IC}}$

Keterangan :

$\mathrm{NCF}=$ Nilai rata-rata core factor

$\mathrm{NC}=$ Jumlah total nilai core factor

IC = Jumlah item core factor

Sedangkan untuk perhitungan secondary factor dapat ditunjukkan pada rumus di bawah ini :

NSF $=\frac{\sum \mathrm{NS}}{\sum \mathbf{I S}}$

Keterangan :

$\mathrm{NSF}=$ Nilai rata-rata secondary factor

NS = Jumlah total nilai secondary factor

IS = Jumlah item secondary factor

Untuk pengelompokkan bobot nilai gap dapat dilihat pada perhitungan aspek pendidikan terakhir, kapasitas intelektual, sikap kerja, perilaku dan pengalaman kerja sebagai berikut:

a. Pendidikan Terakhir

Untuk perhitungan core factor dan secondary factor untuk aspek pendidikan terakhir dengan terlebih dahulu menentukan sub aspek mana yang menjadi core factor dari aspek pendidikan terakhir (sub aspek yaitu D3, D4 dan S1) maka sub aspek sisanya akan menjadi secondary factor, kemudian nilai core factor dan secondary factor ini dijumlahkan sesuai rumus.

$\begin{array}{ll}\text { Indah Pratiwi } & \mathrm{NCF}=\frac{4+4+2}{3}=\frac{10}{3}=3,3 \\ & \mathrm{NSF}=\frac{4+3}{2}=\frac{7}{2}=3,5 \\ \text { Utami Sari } & \mathrm{NCF}=\frac{2+4+2}{3}=\frac{8}{3}=2,6 \\ & \mathrm{NSF}=\frac{3+3}{2}=\frac{6}{2}=3 \\ \text { Reni Ramadhani } & \mathrm{NCF}=\frac{2+4+4,5}{3}=\frac{10,5}{3}=3,5 \\ & \mathrm{NSF}=\frac{5+4}{2}=\frac{9}{2}=4,5\end{array}$




$$
\begin{array}{ll}
\text { Shinta Maulida } & \mathrm{NCF}=\frac{2+4+2}{3}=\frac{8}{3}=2,6 \\
& \mathrm{NSF}=\frac{4+4}{2}=\frac{8}{2}=4 \\
\text { Deni Ananda } & \mathrm{NCF}=\frac{2+3,5+2}{3}=\frac{7,5}{3}=2,5 \\
& \mathrm{NSF}=\frac{4+3}{2}=\frac{7}{2}=3,5
\end{array}
$$

Tabel 11. Bobot Nilai Gap Aspek Pendidikan Terakhir

\begin{tabular}{lllllllll}
\hline No & Nama & SMA & D1 & D3 & D4 & S1 & NCF & NSF \\
\hline 1 & Indah Pratiwi & -1 & -2 & -1 & -1 & -3 & 3,3 & 3,5 \\
2 & Utami Sari & -2 & -2 & -3 & -1 & -3 & 2,6 & 3 \\
3 & Reni Ramadhani & 0 & -2 & -3 & -1 & 1 & 3,5 & 4,5 \\
4 & Shinta Maulida & -1 & -1 & -3 & -1 & -3 & 2,6 & 4 \\
5 & Deni Ananda & -1 & -2 & -3 & 2 & -3 & 2,5 & 3,5 \\
\hline
\end{tabular}

4. Perhitungan Nilai Total

Dari hasil perhitungan dari tiap-tiap aspek di atas, kemudian dihitung nilai total berdasarkan dari core factor dan scondary factor diperkirakan berpengaruh terhadap kinerja tiap-tiap profil. Berikut perhitungan dapat dilihat pada rumus dibawah ini:

$\mathrm{N}=(\mathbf{x}) \% \mathrm{NCF}+(\mathbf{x}) \% \mathrm{NSF}$

Keterangan:

$\mathrm{N} \quad=$ Nilai total dari kriteria

$\mathrm{NCF}=$ Nilai rata-rata core factor

$\mathrm{NSF}=$ Nilai rata-rata secondary factor

$(\mathrm{x}) \%=$ Nilai persen yang diinputkan

Untuk lebih jelasnya perhitungan nilai total terlebih dahulu menentukan nilai persen yang di input yaitu core factor $60 \%$ dan secondary factor $40 \%$ kemudian nilai core factor dan scondary factor ini dijumlahkan sesuai rumus dan hasilnya dapat dilihat pada perhitungan aspek pendidikan terakhir, kapasitas intelektual, sikap kerja, perilaku dan pengalaman kerja.

a. Pendidikan Terakhir

$\begin{array}{lll}\text { Indah Pratiwi } & =(60 \% \times 3,3)+(40 \% \times 3,5) & =3,3 \\ \text { Utami Sari } & =(60 \% \times 2,6)+(40 \% \times 3) & =2,7 \\ \text { Reni Ramadhani } & =(60 \% \times 3,5)+(40 \% \times 4,5) & =3,9 \\ \text { Shinta Maulida } & =(60 \% \times 2,6)+(40 \% \times 4) & =3,1 \\ \text { Deni Ananda } & =(60 \% \times 2,5)+(40 \% \times 3,5) & =2,9\end{array}$

Tabel 12. Nilai Total Gap Aspek Pendidikan Terakhir

\begin{tabular}{lllll}
\hline No & Nama & NCF & NSF & N \\
\hline 1 & Indah Pratiwi & 3,3 & 3,5 & 3,3 \\
2 & Utami Sari & 2,6 & 3 & 2,7 \\
3 & Reni Ramadhani & 3,5 & 4,5 & 3,9 \\
4 & Shinta Maulida & 2,6 & 4 & 3.1 \\
5 & Deni Ananda & 2,5 & 3,5 & 2,9 \\
\hline
\end{tabular}

5. Perhitungan Penentuan Hasil Akhir

Hasil akhir dari proses profile matching adalah rangking dari kandidat atau calon TKI yang berkualitas yang diajukan untuk mengisi suatu jabatan/pekerjaan dan di tempatkan di suatu perusahaan ke luar negeri. Penentuan rangking mengacu pada hasil perhitungan tertentu. Perhitungan tersebut bisa diajukan dengan rumus di bawah ini :

$\mathrm{HA}=10 \% \mathrm{~N} 1+40 \% \mathrm{~N} 2+30 \% \mathrm{N3}+20 \% \mathrm{~N} 4$

Keterangan :

$\mathrm{HA}=$ Hasil Akhir/Rangking

N1 = Nilai Pendidikan Terakhir

N2 = Nilai Kapasitas Intelektual

N3 = Nilai Sikap Kerja

N4 = Nilai Pengalaman Kerja

Sesuai dengan rumus untuk perhitungan rangking diatas, maka hasil dari kandidat calon Tenaga Kerja Indonesia yang berkualitas dapat dilihat pada proses di bawah ini :

$$
\begin{aligned}
\text { Hasil Akhir INDAH PRATIWI } & =(10 \% \times 3,3)+(40 \% \times 4,5)+(30 \% \times 4,4)+(20 \% \times 3,5) \\
& =0,33+1,8+1,32+0,7 \\
& =4,15 \\
& =(10 \% \times 2,7)+(40 \% \times 4,3)+(30 \% \times 4,0)+(20 \% \times 3,4) \\
& =0,27+1,72+1,2+0,68 \\
& =3,87
\end{aligned}
$$




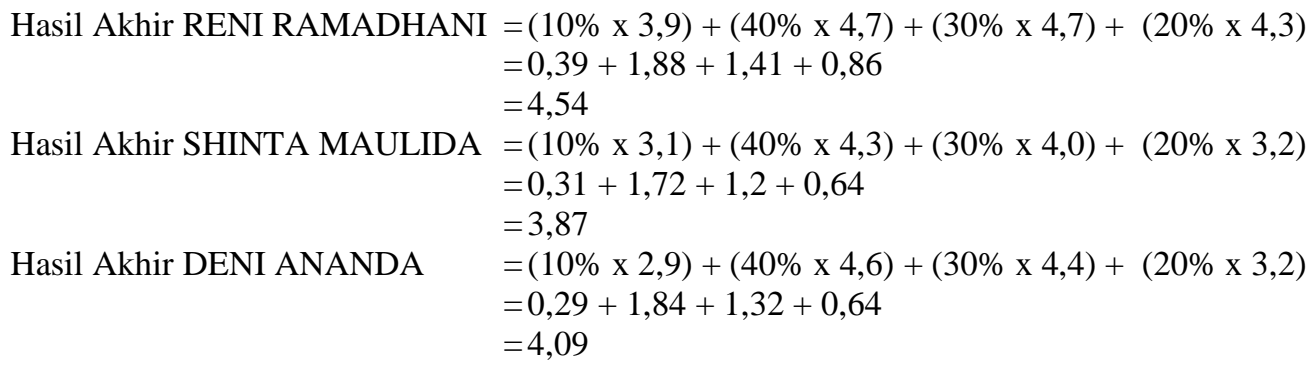

Proses perangkingan diatas dapat dilihat pada tabel di bawah ini :

Tabel 13. Hasil Akhir

\begin{tabular}{lllllll}
\hline No & Nama & N1 & N2 & N3 & N4 & Hasil Akhir \\
\hline 1 & Indah Pratiwi & 3,3 & 4,5 & 4,4 & 3,5 & 4,15 \\
2 & Utami Sari & 2,7 & 4,3 & 4,0 & 3,4 & 3,87 \\
$\mathbf{3}$ & Reni Ramadhani & $\mathbf{3 , 9}$ & $\mathbf{4 , 7}$ & $\mathbf{4 , 7}$ & $\mathbf{4 , 3}$ & $\mathbf{4 , 5 4}$ \\
4 & Shinta Maulida & 3,1 & 4,3 & 4,0 & 3,2 & 3,87 \\
5 & Deni Ananda & 2,9 & 4,6 & 4,4 & 3,2 & 4,09 \\
\hline
\end{tabular}

Dari hasil perhitungan penentuan rangking di atas dapat dilihat bahwa alternatif yang dipilih pada tabel diatas adalah Reni Ramadhani dengan hasil akhir 4,54.

\subsection{Implementasi Program}

Hasil pengujian program menampilkan hasil output dari sebuah input data pada aplikasi yang telah siap. Adapun tampilan hasil pengujian program adalah sebagai berikut:

1. Form Login

Form ini merupakan tampilan awal ketika masuk ke aplikasi. Jika username dan password tidak sesuai maka tidak dapat masuk ke halaman utama. Pengujian form login dapat dilihat pada gambar 1. berikut:

2. Form Data Calon TKI

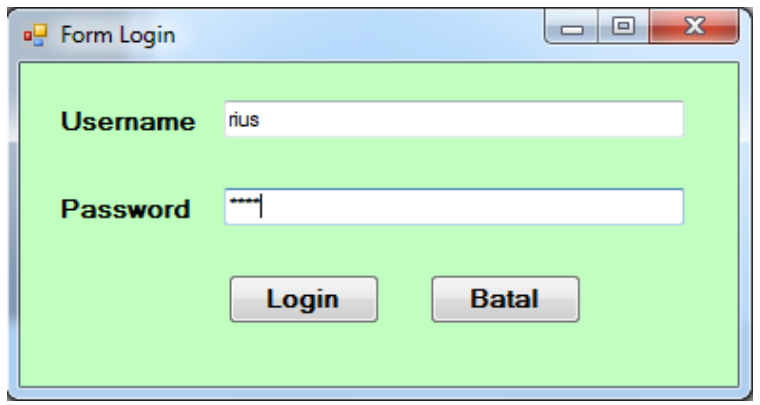

Gambar 1. Pengujian Form Login

Form Data Calon TKI berfungsi untuk memasukkan nama-nama calon Tenaga Kerja Indonesia yang akan diberi penilaian. Form data calon TKI dapat dilihat pada gambar 2. berikut:

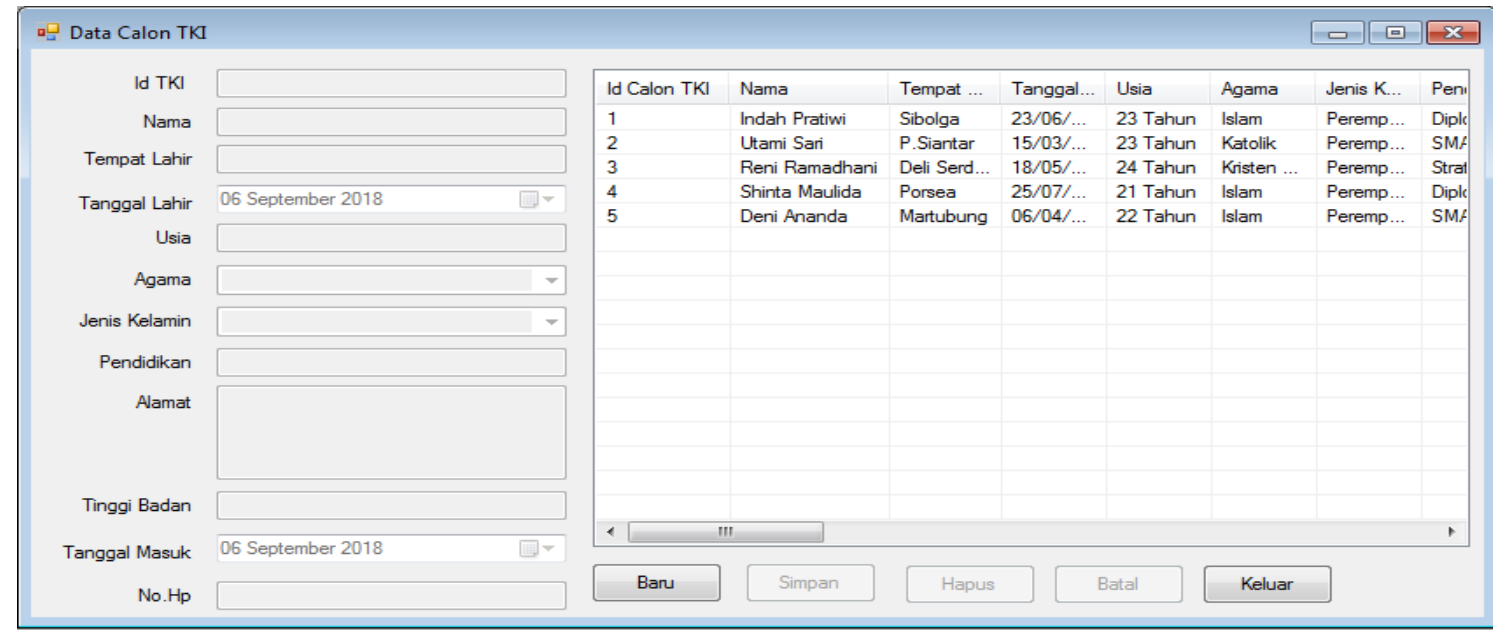

3. Form Nilai Kriteria

Gambar 2. Pengujian Form Data Calon TKI

Pada Form ini digunakan untuk memasukkan nilai-nilai sub kriteria pada masing-masing calon TKI, sehingga 
didapatkan hasil pada form hasil akhir. Form nilai kriteria dapat dilihat pada gambar 3. berikut:

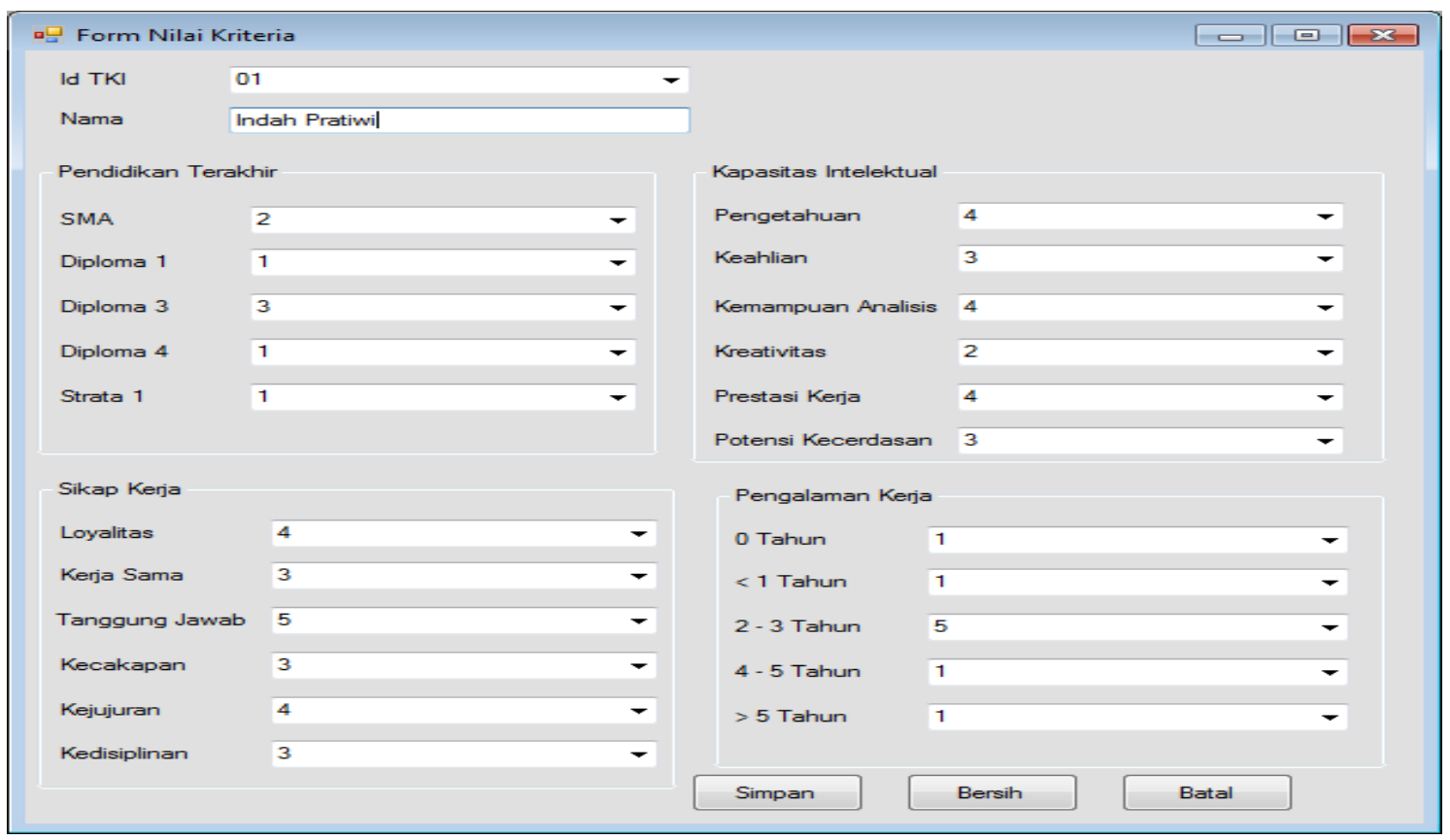

4. Form Hasil Penilaian TKI

Gambar 3. Pengujian Form Nilai Kriteria

Pada form ini akan dilakukan sebuah proses perhitungan sesuai dengan langkah-langkah menggunakan metode Profile Matching dan akan menampilkan hasil dari nilai bobot dan proses perhitungan lainnya. Form hasil penilaian TKI dapat dilihat pada gambar 4. berikut:

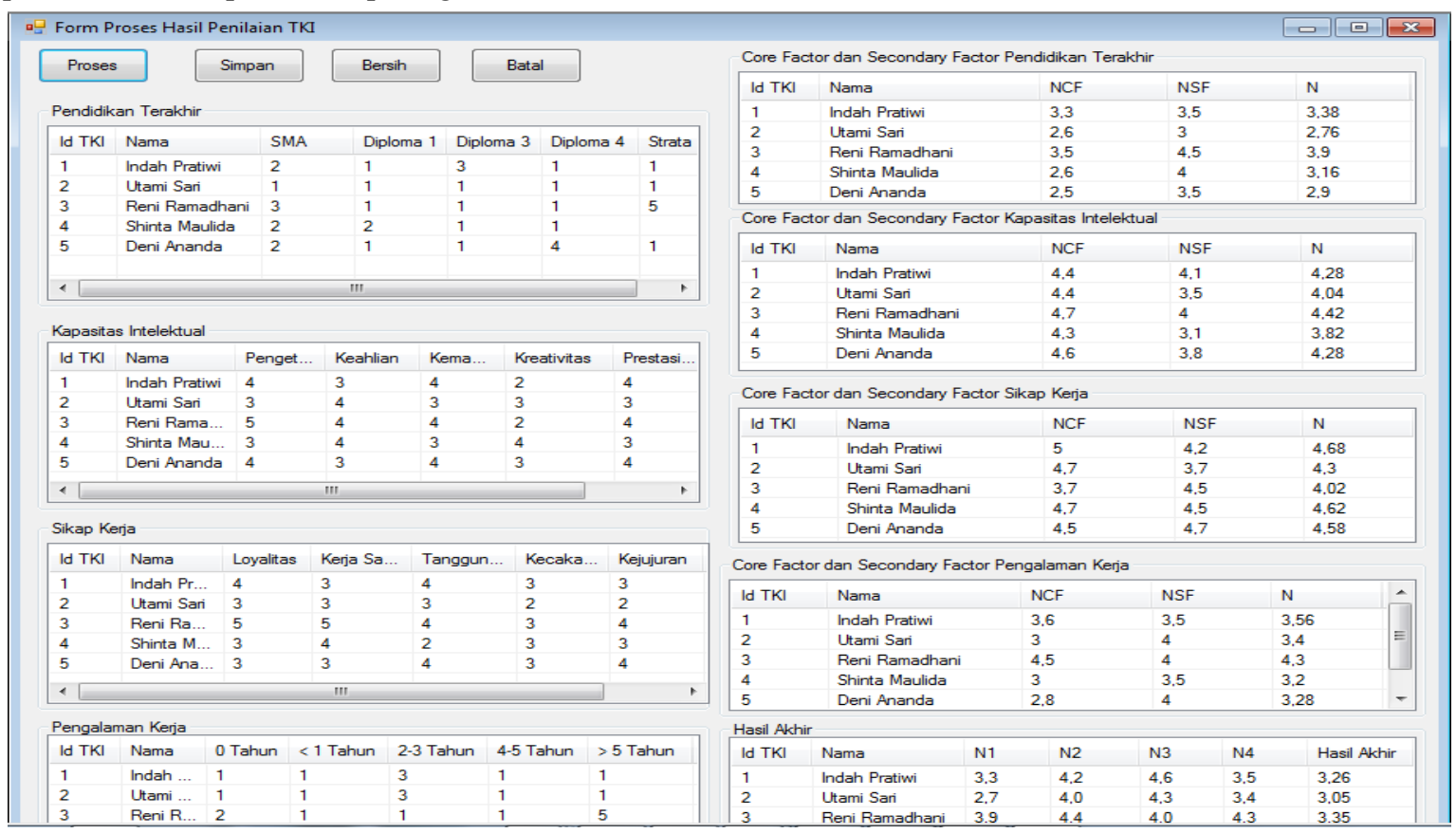

Gambar 4. Pengujian Form Hasil Akhir Penilaian TKI.

\section{KESIMPULAN}

Dari hasil yang penulis lakukan terhadap penelitian ini penulis dapat menarik beberapa kesimpulan yang terkait dengan proses penelitian maupun dengan isi dari penelitian itu sendiri. Adapun kesimpulan - kesimpulan tersebut adalah sebagai berikut :

1. Dalam proses pemilihan Tenaga Kerja Indonesia (TKI) berdasarkan kualitas pada PT. Adila Prezkifarindo Duta tergolong masih manual, dimana belum ada sebuah sistem untuk membantu dalam pemilihan TKI yang berkualitas sehingga memerlukan waktu yang lama untuk penilaiannya serta proses pemilihan yang dilakukan kurang efektif. 
2. Dengan implementasi metode Profile Matching ini dapat membantu dan mempercepat proses pemilihan Tenaga Kerja Indonesia berdasarkan kualitas pada PT. Adila Prezkifarindo Duta.

3. Hasil perhitungan Profile Matching yang diterapkan ini, memanfaatkan sebuah perangkat lunak yaitu Visual Basic 2008 sebagai perangkat untuk menampilkan keluaran hasil perangkingan / nilai akhir tertinggi dari setiap calon TKI, sehingga dapat diketahui bahwa calon Tenaga Kerja Indonesia yang mendapatkan hasil akhir tertinggi yang layak diterima untuk menjadi Tenaga Kerja Indonesia yang berkualitas.

\section{REFERENCES}

[1] M. Kusrini, Konsep dan Aplikasi Sistem Pendukung Keputusan, Yogyakarta: Andi, 2007.

[2] H. Purwanto, "Penerapan Metode Profile Matching dalam Sistem Pendukung Keputusan Penilaian Kinerja Karyawan Pada PT. Hyudan Mobil Indonesia Cabang Kalimantan".

[3] Andi Anto Tri Susilo, "Penerapan Metode Profile Matching Pada Sistem Pendukung Keputusan Penilaian Ketua Program Studi (Studi Kasus: Program Studi Teknik Informatika, STMIK Musi Rawas)" Jurnal Sistem Informasi (JSI), VOL. 5, NO. 2, no. ISSN 2579-8901, P. 92, 2017.

[4] T. Sutabri, Analisis Sistem Informasi, Jakarta: Andi, 2012.

[5] E. L. R. A. I. Dwi Citra Hartini1, "Sistem Pendukung Keputusan Pemilihan Hotel Di Kota Palembang Dengan Metode Simple Additive Weighting (SAW)," Jurnal Sistem Informasi (JSI), Vols. VOL. 5, NO. 1, no. ISSN 2355-4614, P. 549, 2013.

[6] H. Rohayani, "Analisis Sistem Pendukung Keputusan Dalam Memilih Program Studi Menggunakan Metode Logika Fuzzy," Jurnal Sistem Informasi (JSI), Vols. VOL. 5, NO. 1,, no. ISSN 2085-1588, p. 532, 2013.

[7] Wikipedia, "Wikipedia Bahasa Indonesia," WIKIMEDIA, 07 April 2013. [Online]. Available: https://id.wikipedia.org/wiki/Kualitas [Accessed 07 April 2013].

[8] Priranda Widara Ananta1, Sri Winiarti 2, "SISTEM PENDUKUNG KEPUTUSAN DALAM PENILAIAN KINERJA PEGAWAI UNTUK KENAIKAN JABATAN PEGAWAI MENGGUNAKAN METODE GAP KOMPETENSI (STUDI KASUS PERUSAHAAN PERKASA JAYA COMPURETAIL)," Jurnal Sarjana Teknik Informatika, vol. Volume 1 Nomor 2, no. ISSN: 2338-5197, p. 576, 2013.

[9] P. Sulistyorini, "Pemodelan Visual dengan Menggunakan UML dan Rational Rose," Jurnal Teknologi Informasi DINAMIK, Vols. Volume XIV, No.1, no. ISSN : 0854-9524, p. 24, 2009.

[10] W. Komputer, Membuat Aplikasi Client Server dengan Visual Basic 2008, Semarang: ANDI, 2010.

[11] S. M. Primananda Arif Aditya, Dasar-Dasar Pemrograman Database Desktop dengan Visual Basic.Net 2008, Surakarta: PT. ELEX MEDIA KOMPUTINDO, 2012.

[12] Fathansyah, BASIS DATA, Bandung: Informatika Bandung, 2015. 